\title{
Productivity and sanitary and hygienic qualities of the meat of landrace pigs of different blood types, fattened in the industrial zone
}

\author{
V.V. Tedtova ${ }^{1}$, M.S. Gazzaeva ${ }^{2}$, Z.A. Kubatieva ${ }^{2}$, M.I. Klementyev ${ }^{3}$, \\ R.B. Temiraev ${ }^{1,2}$, K.B. Temiraev ${ }^{1}$, A.V. Khmelevskaya ${ }^{4}$
}

\begin{abstract}
${ }^{1}$ North-Caucasian Mining and Metallurgical Institute (State Technological University), Vladikavkaz 362021; ${ }^{2}$ Gorsky State Agrarian University, 362040, Vladikavkaz, 37 Kirov Street; ${ }^{3}$ Federal Science Center for Animal Husbandry named after Academy Member L.K. Ernst 142132,Moscow region, Podolsk City district, Dubrovitsy settlement, house $60 ;{ }^{4}$ North-Ossetian State University named after K.L. Khetagurov, Vladikavkaz, 362025, Russian Federation.

Corresponding authors e-mail: bv_viktoria@mail.ru
\end{abstract}

Journal of Livestock Science (ISSN online 2277-6214) 12: 331-335

Received on 3/10/21; Accepted on 10/11/21; Published on 8/12/21

doi. 10.33259/JLivestSci.2021.331-335

\begin{abstract}
In order to increase the adaptive qualities, meat productivity and consumer qualities of pork produced in the industrial zone of the Republic of North Ossetia - Alania (Russia), introductory mating of Landrace Danish breeding sows (LDB) with breeding boars producing large white breeds (LWB) is carried out, and subsequently, crossbreeds of the 1-st and 2-nd generations are mated with Landrace breeding boars. The investigation purpose was to conduct a comparative control for the consumer qualities of the store pigs meat of the Landrace Danish breeding (LDB) and their cross-breeds of different pedigree on a large white breed (LWB) according to the scheme: control - well-bred Landrace (LDB) animals: 1-st check - 1/2 LDB 1/2 LWB yelts; 2-nd check - 3/4 LDB 1/4 LWB animals and 3-rd check - 7/8 LDB 1/8 LWB yelts. Compared with the control group, there are significantly $(\mathrm{P}<0.05)$ better indexes of preslaughter live weight by $12.02 \mathrm{~kg}$, slaughter weight - by $10.74 \mathrm{~kg}$, slaughter yield - by $1.48 \%$, chilled carcass weight - by $9.70 \mathrm{~kg}$, the carcass yield - by $2.14 \%$ and the weight of the rear third of the half carcass - by $1.01 \mathrm{~kg}$, the area of the «muscle eye» -1 by $2.09 \mathrm{~cm}^{2}$ and the loin yield - by $1.46 \mathrm{~kg}$ were yelts of the $3 \mathrm{rd}$ check group. The best indexes of chemical composition and biological fullness were the yelt meat of the 3 check group, reliably $(\mathrm{P}<0.05)$ surpassing control on the content of dry matter by $0.72 \%$, protein - by $0.8 \%$, the size of protein quality index (PQI) - by 6.6\%. Compared to the animal meat of the control group, the meat sample of the yelts of the 3 -rd check group was inferior in terms of energy value by $2.03 \mathrm{kcal} / 100 \mathrm{~g}$. The animals in the 3 -year-old group (7/8 LDB x 1/8 LWB) had a reliably lower concentration of zinc by 1.90 times, lead - by 1.68 and cadmium - by 1.61 times, respectively.
\end{abstract}

Key words: young pigs; Landrace breed; fattening; heavy metals; slaughter indicators; physicochemical composition of meat; environmental safety. 


\section{Introduction}

For cooking kebabs, meat from pigs of different breed types is used: meat, bacon, combined (porky) breeds, but to ensure high consumer properties of kebabs, first of all, the ratio of protein and fat in pork should be taken into account. In this respect, it is preferable to use the purely meat breed pigs with the more optimal ratio because of a lower proportion of fat, but protein is more (Kairov et al., 2020; Temiraev et al., 2020; Sukhanova et al., 2018; Tsalieva et al., 2017).

In the North Caucasus, including in North Ossetia - Alania, the most common breed of pigs is the large white breed (LWB), which belongs to the combined breeds. Animals of this breed are very well adapted to local conditions, including ecology. Due to the increased emission of high-density metals into the environment, the Republic of North Ossetia - Alania is one of the most polluted territories in the Russian Federation due to the large list of non-ferrous metallurgy enterprises in the city of Vladikavkaz, such as JSC «Electrozinc», JSC «Pobedit», etc. Recently, however, producers have begun to import high-yielding meat breeds, among which the animals of Landrace Danish breeding (LDB) distinguish for their excellent slaughter and meat qualities. But they are less adapted to local environmentalconditions that causes a decrease in their meat productivity and the quality of pork (Hamikoeva et al., 2021; Kokaeva et al., 2017; Temiraev et al., 2008; Pogodaev et al., 2017; Temiraev et al., 2017).

Taking this into account, in order to increase the adaptive qualities, meat productivity and consumer qualities of pork produced in the technogenic zone of the Republic of North Ossetia - Alania, introductory mating of Landrace Danish breeding sows (LDB) with breeding boars producing large white breeds (LWB) is carried out, and subsequently, crossbreeds of the 1-st and 2-nd generations are mated with Landrace breeding boars (Chabaev et al., 2018; Kokaeva et al., 2020; Tedtova et al., 2013; Temiraev et al., 2017).

The investigation purpose was to conduct a comparative control for the consumer qualities of the store pigs meat of the Landrace Danish breeding (LDB) and their crossbreeds of different pedigree on a large white breed (LWB) according to the scheme: control -well-bred Landrace (LDB) animals: 1 -st check - 1/2 LDB 1/2 LWB yelts; 2-nd check - 3/4 LDB 1/4 LWB animals and 3-rd check - 7/8 LDB 1/8 LWB yelts, fattened in the technogenic zone of RNO -Alania, as well as dish samples «Pork kebab», for which the animals meat of the specified pedigree was used in the recipe.

\section{Material and methods}

The experiment was carried out on the basis of a pig farm of an agricultural production cooperative "Vesna" (Republic of North Ossetia - Alania, Russia) (Longitude: 44 $40^{\prime} 04$ " East, Latitude: 43 02'12 "North. Altitude: $671 \mathrm{~m}$ ).

In the course of our investigations, the subjects of investigations were:

- when obtaining meat for processing - different pedigree hog carcasses on large white breeding (LWB) and Landrace Danish breeding (LDB), slaughtered at the age of 7.5 months;

- dish samples, cooked according to the recipe «Pork kebab», from the pork loin of different pedigree.

To obtain different pedigree hog carcasses for large white breeding (LWB) and Landrace Danish breeding (LDB), we fed store pigs for meat production of different pedigree on large white breeding (combined or porky type), selected at the age of 2 months. At the same time, the introductory mating of Landrace Danish breeding sows (LDB) with breeding boars producing large white breeds (LWB) was carried out, and subsequently, crossbreeds of the 1-st and 2-nd generations were mated with Landrace breeding boars.

In accordance with the investigation scheme in the course of fattening store pigs at the age of two months formed, on the principle of analogue pairs (taking into account gender, age, breed, origin and live mass) 4 yelt groups of 15 heads each:

- control- well-bred Landrace (LDB) animals:

- 1-st check - 1/2 LDB x 1/2 LWB yelts;

- 2-nd check - 3/4 LDB x 1/4 LWB animals

- 3-rd check - 7/8 LDB x 1/8 LWB yelts.

Table 1 shows the composition of the daily diet of fattened animals when they reach a body weight of 100$120 \mathrm{~kg}$.

The experimental animals were fed at the age of 60 days and the experiment was completed when the animals of the control group reached a live weight of more than $100 \mathrm{~kg}$. At the same time, a control slaughter was carried out.

After reaching the live weight of $100 \mathrm{~kg}$, the pigs of the control group were slaughtered.For this, 3 typical animals were selected from each group, corresponding in live weight to the average indicators for the group. In accordance with the generally accepted technique, after slaughter of animals, the weight of the steam room and chilled carcasses, internal fat was determined, and the slaughter yield was also calculated.

The resulting digital material was processed biometrically using the information program Excel. 
Table 1 - Daily ration for piglets with a live weight of $100-120 \mathrm{~kg}$

\begin{tabular}{|c|c|c|c|}
\hline Stern & Units & Requirement rate & $\begin{array}{c}\text { The content of feed and } \\
\text { nutrients in the diet }\end{array}$ \\
\hline Fodder beets & $\mathrm{Kg}$ & & 3.0 \\
\hline Gash barley & $\mathrm{Kg}$ & & 1.9 \\
\hline Gash corn & $\mathrm{Kg}$ & & 0.8 \\
\hline Sunflower meal & $\mathrm{Kg}$ & & 0.1 \\
\hline Fresh return & $\mathrm{Kg}$ & & 2.0 \\
\hline Clover grass meal & $\mathrm{Kg}$ & & 0.3 \\
\hline Table salt & $\mathrm{G}$ & 20 & 20.0 \\
\hline Precipitate & $\mathrm{G}$ & & 40.0 \\
\hline Premix & $\mathrm{G}$ & & 10.0 \\
\hline \multicolumn{4}{|c|}{ Contained: } \\
\hline exchange energy & $\mathrm{Mj}$ & 45.4 & 46.2 \\
\hline dry matter & $\mathrm{Kg}$ & 3.20 & 3.22 \\
\hline crude protein & $\mathrm{G}$ & 483 & 499 \\
\hline lysine & $\mathrm{G}$ & 21.1 & 21.7 \\
\hline methionine + cystine & $\mathrm{G}$ & 12.7 & 17.2 \\
\hline crude fiber & $\mathrm{G}$ & 224 & 243 \\
\hline calcium & $\mathrm{G}$ & 26.0 & 26.0 \\
\hline phosphorus & $\mathrm{G}$ & 21.0 & 21.0 \\
\hline gland & $\mathrm{mg}$ & 259 & 485 \\
\hline copper & $\mathrm{mg}$ & 38.0 & 38.0 \\
\hline zinc & $\mathrm{mg}$ & 186 & 314 \\
\hline lead & $\mathrm{mg}$ & - & 29.17 \\
\hline cadmium & $\mathrm{mg}$ & - & 1.60 \\
\hline
\end{tabular}

\section{Results and discussion}

When organizing the feeding of the experimental livestock, research was constantly conducted on the presence of the level of $\mathrm{Zn}, \mathrm{Cd}, \mathrm{Pb}$ salts in the composition of the applied diets. At the same time, the excess of the MPC values in the diets of animals of the compared groups in the presence of zinc salts by 76.24-77.26\%, cadmium salts - by 71.44-72.44\% and lead salts - by 73.56-74.20\% was found.

In order to obtain different pedigree hog carcasses for large white breed (LWB) and Landrace Danish breeding (LDB) under the conditions of the Republic of North Ossetia -Alanya we fed Landrace store pigs for meat production of different pedigree on large white breeding. The slaughter indexes are shown and the linear parameters of hog carcasses are shown in Table 2.

Compared with the control group, there are significantly $(\mathrm{P}<0.05)$ better indexes of preslaughter live weight by $12.02 \mathrm{~kg}$, slaughter weight - by $10.74 \mathrm{~kg}$, slaughter yield - by $1.48 \%$, chilled carcass weight - by $9.70 \mathrm{~kg}$, the carcass yield - by $2.14 \%$ and the weight of the rear third of the half carcass - by $1.01 \mathrm{~kg}$, the area of the «muscle eye» -1 by $2.09 \mathrm{~cm}^{2}$ and the loin yield - by $1.46 \mathrm{~kg}$ were yelts of the $3 \mathrm{rd}$ check group.

Indicators of chemical composition, biological value protein and sanitary and hygienic properties of the meat of experimental gilts are shown in Table 3.

Maximum permissible concentrations (MPC) for fillets are: for zinc $-70 \mathrm{mg} / \mathrm{kg}$, cadmium $-0.05 \mathrm{mg} / \mathrm{kg}$ and lead $-0.5 \mathrm{mg} / \mathrm{kg}$.

The best indexes of chemical composition and biological fullness were the yelt meat of the 3 check group, reliably $(\mathrm{P}<0.05)$ surpassing control on the content of dry matter by $0.72 \%$, protein - by $0.8 \%$, the size of protein quality index (PQI) - by 6.6\%. Compared to the animal meat of the control group, the meat sample of the yelts of the 3-rd check group was inferior in terms of energy value by $2.03 \mathrm{kcal} / 100 \mathrm{~g}$.

The animals in the 3-year-old group (7/8 LDB x 1/8 LWB) had a reliably lower concentration of zinc by 1.90 times, lead - by 1.68 and cadmium - by 1.61 times, respectively. Moreover, the store pigs of the 3-rd check group have the concentration that did not exceed the maximum allowable concentrations (MAC) in any case.

In the compared samples of loin from the yelt carcasses of the compared groups studied indexes of waterholding capacity, diameter of muscle fiber (Table 4) and $\mathrm{pH}$ of meat, determined immediately after slaughter, as well as after 24 hours of soaking.

According to the data obtained, the highest level of water-holding capacity, muscle fiber diameter was characteristic of the store pigs meat of the 3rd check group (7/8 LDB x 1/8 LWB), reliably (P<0.05) surpassing the control analogues in these indexes by $7.97 \%$ and $5.10 \mathrm{mim} /$

The animal meat $\mathrm{pH}$ value of the compared group immediately after slaughter, as well as after 24 hours of soaking, was within the normal range. 
Table 2- Lethal indicators of experimental pigs

\begin{tabular}{|l|c|c|c|c|}
\hline \multirow{2}{*}{\multicolumn{1}{|c|}{ Index }} & \multicolumn{4}{c|}{ Group } \\
\cline { 2 - 5 } & control & 1-st check & 2-nd check & 3-rd check \\
\hline Pre-slaughter live weight, $\mathrm{kg}$ & $102.70 \pm 1.3$ & $110.37 \pm 1.5$ & $112.30 \pm 1.3$ & $114.72 \pm 1.4$ \\
\hline Slaughter weight, kg & $77.24 \pm 1.5$ & $83.83 \pm 1.4$ & $85.51 \pm 1.5$ & $87.98 \pm 1.1$ \\
\hline Chilled carcass weight, $\mathrm{kg}$ & $61.95 \pm 1.2$ & $67.71 \pm 1.1$ & $69.22 \pm 1.2$ & $71.65 \pm 0.9$ \\
\hline Carcass yield,\% & 60.32 & 61.35 & 61.64 & 62.46 \\
\hline Lethal output,\% & 75.21 & 75.95 & 76.15 & 76.69 \\
\hline Carcass length, cm & $97.67 \pm 0.2$ & $100.77 \pm 0.3$ & $101.51 \pm 0.4$ & $102.88 \pm 0.4$ \\
\hline $\begin{array}{l}\text { Weight of the rear third of the } \\
\text { half carcass, kg }\end{array}$ & $10.21 \pm 0.12$ & $11.08 \pm 0.14$ & $11.22 \pm 0.13$ & $11.68 \pm 0.13$ \\
\hline Muscle eye area, cm & & & & $31.44 \pm 0.18$ \\
\hline Loin weight, kg & $29.35 \pm 0.17$ & $30.36 \pm 0.20$ & $30.75 \pm 0.24$ & $9.67 \pm 0.11$ \\
\hline
\end{tabular}

Table 3 - Chemical composition, biological value protein and sanitary and hygienic qualities of pig meat

\begin{tabular}{|l|c|c|c|c|}
\hline \multirow{2}{*}{\multicolumn{1}{c|}{ Index }} & \multicolumn{4}{c|}{ Group } \\
\cline { 2 - 5 } & control & 1 -st check & 2-nd check & 3-rd check \\
\hline Dry matter, \% & $26.94 \pm 0.10$ & $27.37 \pm 0.12$ & $27.66 \pm 0.14$ & $27.19 \pm 0.19$ \\
\hline Protein, \% & $21.02 \pm 0.09$ & $21.56 \pm 0.08$ & $21.89 \pm 0.07$ & $21.59 \pm 0.08$ \\
\hline Fat, $\%$ & $4.90 \pm 0.02$ & $4.83 \pm 0.05$ & $4.80 \pm 0.04$ & $4.60 \pm 0.04$ \\
\hline Tryptophan, mg & 336.8 & 340.4 & 341.7 & 338.7 \\
\hline Oxyproline, mg & 43.1 & 42.1 & 41.0 & 42.0 \\
\hline Protein-quality index (PCP) & $7.81 \pm 0.06$ & $8.08 \pm 0.04$ & $8.33 \pm 0.05$ & $8.06 \pm 0.07$ \\
\hline Energy value 100 g /, kcal & 360.5 & 359.45 & 359.24 & 358.47 \\
\hline Zinc (MPC = 70 mg / kg) & $74.13 \pm 0.15$ & $64.56 \pm 0.18$ & $56.31 \pm 0.22$ & $39.07 \pm 0.11$ \\
\hline Cadmium (MPC =0.05 mg/kg) & $0.071 \pm 0.001$ & $0.065 \pm 0.001$ & $0.059 \pm 0.001$ & $0.044 \pm 0.001$ \\
\hline Lead (MPC =0.5 mg / kg) & $0.62 \pm 0.002$ & $0.55 \pm 0.001$ & $0.49 \pm 0.002$ & $0.37 \pm 0.003$ \\
\hline
\end{tabular}

Table 4 - Some technological properties of pork

\begin{tabular}{|l|c|c|c|c|}
\hline \multirow{2}{*}{\multicolumn{1}{|c|}{ Index }} & \multicolumn{4}{c|}{ Group } \\
\cline { 2 - 5 } & control & 1-st check & 2-nd check & 3-rd check \\
\hline Water-holding capacity,\% & $58.24 \pm 0.10$ & $60.19 \pm 0.19$ & $63.57 \pm 0.12$ & $66.21 \pm 0.14$ \\
\hline Muscle fiber diameter, $\mu \mathrm{m}$ & $39.4 \pm 0.29$ & $41.1 \pm 0.32$ & $41.5 \pm 0.31$ & $44.5 \pm 0.37$ \\
\hline $\mathrm{pH}_{1}$ & $5.82 \pm 0.04$ & $5.69 \pm 0.05$ & $5.86 \pm 0.08$ & $5.84 \pm 0.07$ \\
\hline $\mathrm{pH}_{24}$ & $5.64 \pm 0.02$ & $5.45 \pm 0.04$ & $5.68 \pm 0.05$ & $5.62 \pm 0.04$ \\
\hline
\end{tabular}

Conclusion.1. It was found that with an excessive background of high-density metals in comparison with well-bred yelts of the Landrace Danish breeding for meat productivity (LDB), animals of the 3-rd generation (7/8 LDB x 1/8 LWB) have the best slaughter indexes for large white breed (LWB).

2. The results of the chemical analysis for the longest muscle of the back showed that, against the control sample, in the meat of animals of the 3-rd check group of calves (7/8 LDB 1/8 LWB), there was a significantly $(\mathrm{P}<0.05)$ higher dry matter content by $0.72 \%$, protein -by $0.8 \%$, the value of the protein-quality index $(\mathrm{PQI})-$ by $6.6 \%$, water-holding capacity - by $7.97 \%$ and muscle fiber diameter -by 5.10 microns with a decrease in the level of zinc content by 1.90 times, lead -1.68 times and cadmium -1.61 times, respectively.

\section{References}

1) Chabaev M.G., Tedtova V.V., Baeva Z.T., Kononenko S.I., Tarchokov T.T., Chopikashvili L.V. 2018.Effect of different adsorbent doses on the morphological and biochemical composition of blood of bull calvesin detoxification of heavy metals. Journal of Pharmaceutical Sciences and Research. 10(5): 1122-1124.

2) Hamikoeva S.R., Temiraev R.B., Chabaev M.G., Tsis E.Yu., Gappoeva V.S., Khabaeva Z.G., Gagloeva A.R. 2021. Effect of adsorbent and enzyme preparations on productivity of fattening steers with diets containing heavy metals. Journal of Livestock Science 12: 60-64. doi. 10.33259/JLivestSci.2021.60-64

3) Kairov V.R., Kairov A.V., Chabaev M.G., Nekrasov R.V., Temiraev K.B., Tsagaraeva E.F., Bobyleva L.A. 2020. The influence of antioxidant on the productivity and activity of digestive broiler enzymes in reducing the risk of T-2 toxin. Journal of Livestock Science 11: 85-89. doi. 10.33259/JLivestSci.2020.85-89.

4) Kokaeva M.G., Temiraev R.B., Dzhaboeva A.S., Osikina R.V., Gazzaeva M.S., Shugusheva L.H., Sattsaeva I.K., Nerovnykh L.P., Arutyunova G.Y., Efendiev B.S. 2020. Method for increasing the ecological and food values of milk and dairy products. Journal of Livestock Science 11: 14-19 doi. 10.33259/JLivestSci.2020.14-19. 
5) Kokaeva, M.G., Temiraev, R.B., Beslaneev, E.V., Cherchesova, S.K., Kubatieva (Gutieva), Z.A. and Kozyrev, S.G. 2017. Influence of antioxidant and adsorbent on the processes of digestive and intermediate metabolism in lacting cows during denitrification. Journal of Pharmaceutical Sciences and Research. 9 (12): 2401-2404.

6) Pogodaev V.A., Arilov A.N., Shevhuzhev A.F., Marynich A.P., Kochkarov R.H., Research Journal of Pharmaceutical, Biological and Chemical Sciences,8(1),1086- 1090 (2017).

7) Sukhanova S.F., Kononenko S.I., Temiraev R.V., Tarchokov T.T., Baeva Z.T., Bobyleva L.A., Shipshev B.M., 2018. Journal of Pharmaceutical Sciences and Research,10, 11, 2969-2971(2018).

8) Tedtova V.V., Baev Z.T., Dzodziev E.S., Tsopanova Z.Ya., Pilov A.Kh. 2013. Meat productivity of gobies of different breeds fattened in the technogeniczone .Meat industry. - Moscow. 3: 60-62.

9) Temiraev V.H., Baeva A.A., Vityuk L.A., Mamukaev M.N., Yurina N.A., Ktsoeva I.I., Bobyleva L.A., Zagaraeva E.F., Kokov T.N., Vologirova F.A. 2020. Effect of probiotics on digestive metabolism in growing and laying poultry birds. Journal of Livestock Science 11: 33-39.

10) Temiraev V.K., Kairov V.R., Temirayev R.B., Kubatieva Z.A.and Gukezhev V.M., $2017 . \quad$ Ecology, Environment and Conservation,23(1), 554-561.

11) Temiraev, R.B. Heavy metal contamination: how to keep pork safe / R.B. Temiraev, V.R. Kairov, E.S. Khamitsaeva, T.K. Tuaeva 2008. Compound feed. 4: 34-35

12) Temiraev R.B., Kozhokov M.K., Cherchesova S.K., Kokaeva F.F., Tletseruk I.R. 2017. Method for diminishing the adverse effect of anthropogenic heavy metal pollution on poultry meat products. Journal of Environmental Management and Tourism. 8. 3 (19): 567-573.

13) TsalievaL.V., TemiraevR.B., KononenkoS.I., DzagurovB.A., GazzaevaM.S., GrevtsovaS.A.2017. Ecological and consumer properties of pig meat from different breeds produced in technogenic zone. Journal of Pharmaceutical Sciences and Research. 9(12): 2397-2400. 